\title{
Frit skolevalg og lighed
}

Claus Hansen Ph.d., Forskningsassistent, Center for Studier af Lighed og Multikulturalisme, Københavns Universitet

Det frie skolevalg er problematisk ud fra et ligheds- og fællesskabsideal. Forældrenes rettigheder til at have nære relationer til deres børn strækker sig ikke til at kunne bestemme over børnenes skolegang. Det har konsekvenser for at synet på forskellige modeller for omfordeling af børn mellem skoler.

\section{Indledning}

Den 1. august 2005 trådte loven om mere frit skolevalg i kraft. Lovændringen udvidede forældres ret til at vælge skole, således at forældre nu kan vælge skole uden for bopælskommunen i stedet for, som tidligere, blot inden for bopælskommunen. ${ }^{1}$ Udover den frihed som loven om frit skolevalg giver, har forældre også mulighed for at vælge privat- og friskoler. ${ }^{2}$ Endelig kan friheden til at vælge skole også være indirekte. Selv hvis staten forbød privat- og friskoler og annullerede det frie skolevalg, ville forældre stadig kunne udøve valgfrihed ved at flytte til et andet skoledistrikt.

Det frie skolevalg har været genstand for en del kritik. Kritikere har argumenteret for, at det frie skolevalg vil føre til mere socioøkonomisk og etnisk segregation, fordi resursestærke forældre vil vælge skoler med færre socialt belastede elever. Konsekvensen bliver såkaldte „ghettoskoler" med en stor procentdel tosprogede og resursesvage elever. Og med øget segregation følger øget ulighed, fordi ghettoskoler fastholder de resursesvage elever i nogle uheldige mønstre.

Ser man på empirien, er der meget, som tyder på, at loven om frit skolevalg har haft indvirkning på elevsammensætningen i mange folkeskoler, selvom det er svært at fastslå den præcise årsag til det faldende elevantal i folkeskolen. En undersøgelse foretaget af Rambøll Management (2007) viser, at lovændringen ikke har skabt øget segregering, men påpeger samtidig, at frit skolevalg kan være en medvirkende faktor til segregering. ${ }^{3}$ I Kø- benhavns Kommune går kun halvdelen af eleverne i den lokale skole, en fjerdedel går i privatskole og en fjerdedel går på en anden skole end den lokale skole. Beatrice Schindler Rangvid taler ligefrem om en elevflugt af etnisk danske elever fra de københavnske folkeskoler (Rangvid 2010). Hendes undersøgelse viser, at hvis indvandrerkoncentrationen er højere end $25 \%$, vælger danske forældre den lokale skole fra. I det hele taget er der en tendens til, at højtuddannede etnisk danske forældre gør mere brug af det frie skolevalg, end lavtuddannede etnisk danske forældre. Det forholder sig anderledes med indvandrerforældre. For $80 \%$ af indvandrerforældre er der ingen sammenhæng mellem elevsammensætningen på den lokale skole og hvilken skole de sender deres børn i. De resterende $20 \%$ har en tendens til at vælge den lokale skole fra, hvis koncentrationen af elever med lavtuddannede forældre er for høj - den etniske sammensætning har derimod ingen effekt på deres skolevalg (Rangvid 2010). Muligheden for at vælge privatskole bidrager altså til øget segregering. Når man ser på de store kommuner, tegner der sig et billede af, at flere og flere forældre vælger privatskoler. Antallet af grundskoleelever i privatskoler er steget med $26 \%$ siden 1999, således at 14,8\% af alle grundskoleelever i Danmark nu modtager undervisning på en privatskole. I København og Frederiksberg Kommune er tallet endnu højere: her er det henholdsvis $28 \%$ og $24 \%$ af grundskoleeleverne, der går i en privatskole. Samme tendens finder man i de andre store kommuner. I Odense går $19 \%$ af kommunens grundskolelever i privatskole, mens det i Århus Kommune er godt 14 \%. På landsplan er andelen af privatskoleelever steget fra 13,5 \% i 2007 til 14,8 \% i 2010, mens tallet for Københavns Kommune i samme periode er 3,7 \%. Der er altså tale om en klar og stigende tendens, om end den er noget mere udtalt i de store kommuner.

Hvad vigtigere er: meget tyder på, at privatskoler har social slagside. Ifølge en undersøgelse lavet af centrumvenstre tænketanken Cevea (2010a) går hvert 5. barn 
fra en resursestærk og veluddannet familie i privatskole, mens det kun er hvert 7. barn fra resten af samfundet. Cevea peger ligeledes på, at $48 \%$ af eleverne i privatskoler kommer fra veluddannede hjem, hvorimod det tilsvarende tal for folkeskolen er $33 \%$. Folkeskolen har også en højere andel af indvandrerbørn: I privatskolerne har 19,8 $\%$ af eleverne indvandrerbaggrund, mens dette tal er 26,7 $\%$ i folkeskolen. Det hører med til historien, at de fleste indvandrerelever i den private sektor samler sig på enkelte skoler, gerne religiøse, hvor de udgør $100 \%$. Tallene tyder altså på, at vi oplever en øget segregation i grundskolerne.

Ser man på karaktergennemsnittet på landets grundskoler, tegner der sig et forholdsvis tydeligt billede af, at elevsammensætningen har betydning for den enkelte elevs karakter. I 2007 var 15 ud af de 20 bedst placerede skoler private, og den bedst placerede skole kunne fremvise et snit på 9,7 (Krebs Skole på Østerbro), mens den dårligst placerede skole måtte nøjes med et snit på 6,7 (Blågård Skole på Nørrebro). Beatrice Schindler Rangvid har i et studie vist, at omkring halvdelen af forskellene i skolernes karaktergennemsnit kan forklares ved, at skolerne ikke har de samme elever. Det siger dels noget om skolernes kvalitet, men det siger også noget om, at elevernes sociale baggrund har betydning for karaktergennemsnittet (2008). Skoler med færrest elever med ufaglærte forældre har et karaktergennemsnit på 8,3, mens elever, der går på skoler med flest elever med ufaglærte forældre, har et gennemsnit på 7,3 (Rangvid 2008). Selv om man skal være forsigtig med at drage konklusioner på baggrund af nogle få undersøgelser, tyder en del på, at nogle børn får en bedre uddannelse end andre, og at forældres mulighed for at vælge skole kan forstærke denne ulighed.

Kritikere af det frie skolevalg henviser ofte til lighed og til hvad jeg kalder det kommunitaristiske ideal. Tilhængere af det frie skolevalg, på den anden side, appellerer til forældrenes ret til at vælge, hvilken skole deres barn skal gå på. Sigtet med denne artikel er dels at give en mere præcis karakterisering af disse idealer og relationen mellem dem, for derved at klargøre hvilke normative principper, der er på spil i debatten; dels at kritisere rettighedsargumentet for frit skolevalg. Mere præcist argumenterer jeg for, at forældre ikke har en moralsk ret til frit skolevalg. Det betyder imidlertid ikke, at vi skal opgive det frie skolevalg, eftersom der kan være andre grunde til at bibeholde det, men en sådan klargøring vil alt andet lige give større råderum med hensyn til hvilke politiske tiltag, vi kan gøre brug af, for at imødegå nogle af de negative konsekvenser af frit skolevalg. I det sidste afsnit diskuterer jeg to sådanne konkrete politiske tiltag, Københavnermodellen og Aarhus-modellen, som begge på forskellig vis forsøger at imødegå de uønskede konsekvenser ved det frie skolevalg. Begge modeller er problematiske, men jeg argumenterer alligevel for, at tvangsflytning af elever, som $\mathrm{fx}$ Aarhus-modellen giver mulighed for, kan være den bedste løsning, normativt set.

\section{Lighed i uddannelse}

Idealet om lighed i uddannelse spiller en vigtig rolle i debatten om frit skolevalg. Selv om der er forskellige opfattelser af, hvordan lighed nærmere skal forstås, er der bred enighed om, at lighed er en vigtig værdi. I det følgende skal jeg forsvare en forholdsvis radikal udgave af lighedsidealet. Mit mål er ikke at afdække et fælles lighedsideal, som de forskellige aktører i debatten kan tilslutte sig, men at formulere det lighedsideal, som jeg mener, bør ligge til grund for en normativ vurdering af det frie skolevalg.

Lighedsidealet, som jeg forstår det her, er en radikal version af idealet om lige muligheder. Når man i den offentlige debat taler om vigtigheden af lige muligheder, er det ofte med udgangspunkt i et antidiskriminationsprincip. $\mathrm{Fx}$ at arbejdsgivere ikke må diskriminere på baggrund af socialbaggrund, race, køn og religion. Idealet er, at hvis en person er kvalificeret til et job, er det uretfærdigt, hvis vedkommende fravælges på baggrund af race, køn, religion, eller andre ting, som ikke er relevante for udførelsen af jobbet. Antidiskriminationsprincippet er imidlertid foreneligt med en lang række uligheder i folks muligheder for at opnå goder: Folk er født med forskellige talenter og i forskellige sociale omstændigheder, som gør, at nogle mennesker aldrig vil kunne opnå de samme kvalifikationer som andre, uanset hvor hårdt de arbejder. Det mere radikale lighedsideal, som jeg skal tage udgangspunkt $\mathrm{i}$ her, siger, at ingen må være dårligere stillet end andre ( $\mathrm{fx}$ med hensyn til uddannelse) pga. deres sociale baggrund og medfødte talenter. Det radikale lighedsideal forsøger således ikke blot at sikre lige kvalificerede individer de samme muligheder for at opnå et gode, men at alle har lige muligheder for at opnå lige gode kvalifikationer. ${ }^{4}$

Lighedsidealet hviler på den centrale antagelse, at uddannelsesmæssige uligheder forårsaget af sociale omstændigheder ( $\mathrm{f} x$ forældres valg på barnets vegne) og naturlige omstændigheder (medfødte evner) er uretfærdige, fordi barnet ikke er ansvarligt for dem. Anvendt på uddannelse foreskriver lighedsidealet, at alle børn skal have en lige god uddannelse. Når vi sammenligner børn med lige gode talenter og med samme villighed til at gøre en indsats, er lighedsidealet tilfredsstillet, hvis de modtager en lige stor del af uddannelsesresurserne. Det bliver straks mere kompliceret, når vi sammenligner børn med forskellige talenter. Antag at Anders er meget talentfuld, mens Bente har store indlæringsvanskeligheder. Lighedsidealet vil alt andet lige foreskrive, at Bente skal tilføres flere resurser end Anders for at udligne forskellen mellem dem. ${ }^{5}$ 
Det radikale lighedsideal indfanger mange egalitaristers intuitioner vedrørende fordelingen af uddannelsesresurser. Fx er mange egalitarister imod elitære privatskoler, som man fx kender det fra det engelske system, af den grund, at det skaber et system, hvor nogle børn modtager bedre undervisning end andre børn, simpelthen fordi deres forældre er i stand til at købe en bedre uddannelse. En lignende bekymring opstår i forbindelse med selektive skoler (fx de engelske „grammar schools“), som er skoler for de bedste elever. I den danske skoledebat har der også været tanker fremme om at skabe skoler eller klasser for de bedste elever. Traditionelt har egalitarister været skeptiske overfor den slags skoler, fordi der er en risiko for, at de elever, som ikke får adgang til sådanne skoler, modtager en dårligere uddannelse. Endelig har egalitarister været skeptiske overfor det frie skolevalg. Egalitarister har ofte påpeget, at forældre besidder forskellige evner til at vælge skole, og at denne forskel i høj grad hænger sammen med socialklasse, uddannelsesniveau og indkomst. Fælles for de tre eksempler er, at nogle børn bliver dårligere stillet end andre af grunde, de ikke selv er ansvarlige for.

\section{Det kommunitaristiske ideal}

En stor del af den danske debat om frit skolevalg har drejet sig om, hvorvidt det frie skolevalg vil undergrave enhedsskolen og de værdier, den er baseret på. Enhedsskolen er motiveret af et kommunitaristisk ideal. Tilhængerne af enhedsskolen hævder ikke, at selektive skoler eller elitære privatskoler er uretfærdige, fordi de giver nogle børn bedre muligheder end andre, men at socioøkonomisk segregation i skolesystemet kan medvirke til at undergrave vigtige samfundsværdier såsom solidaritet og sammenhængskraft. Enhedsskolen hviler på en påstand om det værdifulde i, at børn mødes i skolen på tværs af socioøkonomiske og etniske skel. Et velfungerende samfund i almindelighed og en velfærdsstat i særdeleshed hviler på gensidig respekt og solidaritet mellem de forskellige sociale klasser, og folkeskolen kan facilitere en følelse af samhørighed mellem de bedre og dårligere stillede i samfundet. Alternativet er et segregeret samfund, hvor de forskellige sociale klasser lever i separate verdener med megen lidt eller slet ingen kontakt og dermed ringe forståelse for hinandens kultur, værdier og livsomstændigheder. ${ }^{6}$

Ifølge det kommunitaristiske ideal består folkeskolens opgave således i mere end blot at forberede børnene på arbejdslivet; folkeskolen skal derudover være med til at skabe fundamentet for et solidarisk samfund. Oprindeligt var enhedsskolen tænkt som et værn mod socioøkonomisk segregation, men en lignende bekymring opstår i forbindelse med etnisk og religiøs segregation. Antag at vi har et skolesystem uden socioøkonomisk segregation, men med en høj grad af etnisk og religiøs segregation?, $f_{x}$ fordi en stor andel af indvandrerforældrene vælger at sende deres børn i religiøse privatskoler. Et sådant skolesystem vil alt andet lige også være karakteriseret ved en manglende gensidig forståelse og samhørighed, og således mangle den solidaritet, som tilhængerne af enhedsskolen finder så essentiel for et velfungerende samfund. Tilhængerne af det kommunitaristiske bør derfor i lige så høj grad se med skepsis på religiøse friskoler.

Som sagt appellerer fortalerne for enhedsskolen sjældent direkte til lighed. Der er imidlertid flere velkendte mekanismer, som $\mathrm{g} ø r$, at et en realisering af det kommunitaristiske ideal kan føre til mere lighed. For det første bringer middelklasseforældre resurser til skolen i form af større krav til lærerne og større engagement i skolebestyrelsen. For der andet er det mere resursekrævende at undervise dårligere stillede elever, så socialt blandede skoler vil betyde, at der er flere resurser til de svage elever. Endelig er der den såkaldte kammeratskabseffekt, dvs. det forhold, at de bedre elever kan være med til at hive de dårligere elever op (Rangvid 2010). Hvis vi desuden antager, at der er en sammenhæng mellem forældrenes sociale position og børnenes evner, således at de socialt bedre stillede børn også er de dygtigste, vil enhedsskolen være med til at udjævne forskelle i uddannelsesmuligheder. ${ }^{8}$ Enhedsskolen vil ikke blot sikre et mere socialt integreret samfund; den vil også minimere uligheder i uddannelsesmuligheder.

Selvom man således kan nå den samme konklusion - at enhedsskolen er værdifuld - med udgangspunkt i de to idealer, er det vigtigt at være opmærksom på, at der stadig er tale om to forskellige idealer, som både kan supplere hinanden og, givet visse antagelser, være i konflikt. Det skyldes, at det kommunitaristiske ideal fokuserer på grupper, socioøkonomiske og etniske, hvorimod lighedsidealet fokuserer på individer. Forskellen kan belyses med et eksempel. Traditionelt har tilhængere af det kommunitaristiske ideal været skeptiske overfor privatskoler, fordi privatskoler hovedsageligt tiltrækker resursestærke elever fra bestemte socialgrupper. Men antag, at det forholdt sig anderledes. Antag, at privatskoler kun tiltræk dygtige elever, men at der samtidig ikke var en sammenhæng mellem elevernes evner på den ene side og deres sociale og etnisk baggrund på den anden, således at de dygtige elever kom fra alle samfundslag. Hvis det var tilfældet, ville eksistensen af privatskoler ikke bidrage til socioøkonomisk segregation og derfor heller ikke være i konflikt med det kommunitaristiske ideal. Men eftersom et sådant skolesystem ville øge uligheden mellem de gode elever og de dårlige elever, ville det være uforeneligt med lighedsidealet. Hvis tilhængerne af det kommunitaristiske ideal alligevel finder et sådant skolesystem problematisk, er de højst sandsynligt ikke imod socioøkonomisk segregation 
som sådan, men imod segregation, der leder til øget ulighed i uddannelsesmuligheder. Overvej et andet ikke helt urealistisk scenarie, som også illustrerer en mulig konflikt mellem de to idealer. Lad os antage, at det er bedre for elever med dansk som andetsprog at gå i separate klasser, og at disse elever samtidig hører til blandt de svageste. Skabelsen af separate klasser vil finde støtte i lighedsidealet, da det vil fremme uddannelsesmuligheder for en gruppe af de svageste elever og dermed minimere uligheden i uddannelsesmuligheder. Et sådant tiltag ville derimod ikke være foreneligt med det kommunitaristiske ideal, eftersom det vil skabe yderligere social og etnisk segregation. ${ }^{9}$

Pointen er ikke, at socioøkonomisk integration kun har værdi for så vidt det fører til lighed i uddannelsesmuligheder. Selv i ovenstående eksempel, hvor privatskoler og folkeskoler har den samme elevsammensætning socioøkonomisk set, kan man stadig med udgangspunkt i det kommunitaristiske ideal påstå, at det ville være bedre, hvis alle elever gik i folkeskolen. Men det er samtidig klart, at det kommunitaristiske ideal står endnu stærkere, når socioøkonomisk og etnisk segregation også fører til social uretfærdighed i form af ulige uddannelsesmuligheder. Det har ydermere den konsekvens, at vi i visse situationer bliver nødt til at foretage en afvejning af det kommunitaristiske ideal i forhold til lighedsidealet. Med andre ord, hvad er vigtigst, at sikre lige muligheder eller at sikre solidaritet?

\section{Forældrerettigheder}

Både det kommunitaristiske ideal og lighedsidealet tager udgangspunkt $i$, hvad konsekvenserne er for andre børn, hvis man som forældre vælger at sende sit barn i en bestemt skole. Mange vil sikkert mene, at begge idealer undlader en vigtig komponent, nemlig hvad man som forældre har frihed til eller ligefrem pligt til at gøre for sit eget barn. Hvorvidt forældre har frihed til at vægte deres egne børns interesser højere end andres børns interesser bliver især relevant i forbindelse med lighedsidealet, eftersom lighedsidealet med dets krav om, at ingen må være dårligere stillet end andre pga. deres sociale omstændigheder, kan være særdeles krævende med hensyn til, hvad forældre må gøre for deres børn. Som den amerikanske filosof John Rawls skriver:

„It seems that even when fair opportunity (as it has been defined) is satisfied, the family will lead to unequal chances between individuals. Is the family to be rejected then? Taken by itself and given a certain primacy, the idea of equal opportunities inclines in this direction (Rawls 1999, $448)^{\prime \prime}$.
Det er almindelig anerkendt, at graden og karakteren af den stimulation, børn modtager hjemmefra, har indvirkning på deres skolemæssige evner. Veluddannede forældre taler alt andet lige mere med deres børn, drøfter politiske og kulturelle emner, besøger museer, læser historier for deres børn og stimulerer i det hele taget deres børn mere. ${ }^{10}$ Selvom mange forældre uden tvivl ikke er motiveret af et $ø$ nske om, at deres barn skal have en konkurrencemæssig fordel i forhold til andre børn, bliver konsekvensen ikke desto mindre ofte, at nogle børn får dårligere uddannelsesmuligheder end andre, af grunde de ikke selv er skyld i. Ligeledes kan der være mange grunde til at vælge en bestemt privat- eller friskole, men hvis konsekvensen er, at de gode elever samler sig på enkelte skoler, kan det medføre øget ulighed i uddannelsesmuligheder. Hvad mere er, nyere sociologisk og økonomisk forskning har vist, at den ulighed i uddannelsesmuligheder, der skyldes forskellige sociale kår, ikke kan udjævnes udelukkende ved hjælp af omfordelingspolitiske tiltag. Kimen til ulighed bliver sået tidligt $\mathrm{i}$ et barns liv. Lighedsidealet giver derfor en retfærdighedsbaseret grund til at arrangere samfundet således, at forældre ikke har mulighed for at give deres børn en positionel fordel i forhold til andre børn ved fx at vælge en bestemt skole eller ved at læse godnathistorie for deres børn. Lighedsidealet medfører med andre ord, at der er en grund til at forbyde forældre at læse godnathistorier for deres børn og at forældre har en grund til at afstå fra det. ${ }^{11}$ Dette er selvsagt en radikal konklusion med vidtrækkende konsekvenser for forældres forhold til deres børn. Resursestærke børn bliver resurser for de resursesvage børn.

I den danske debat om det frie skolevalg bliver der ofte refereret til forældrenes ret til at vælge deres barns skole. De Konservatives uddannelsesordfører, Rasmus Jarlov, har fx udtalt, at „det er meget vigtigt, at vi giver forældrene ret til at vælge en skole, som de mener passer til deres barn" (Berlingske Tidende den 14. september 2010). At individer har rettigheder, herunder visse rettigheder i forhold til deres børn, som skaber et frirum indenfor hvilket de kan følge deres egne interesser uden indblanding fra staten, er en liberal kongstanke. Det bliver også afspejlet i den Europæiske Menneskerettighedskonvention, som giver forældre ret til at købe uddannelse til deres børn. ${ }^{12}$ Det er imidlertid ikke nok at pege på, at en given politik begrænser forældrenes frihed til at foretage visse valg. Vi har rettigheder, fordi vi har vigtige interesser, som skal beskyttes, og det er disse underliggende interesser og ikke rettighederne i sig selv, som bærer den normative vægt. Det er derfor nødvendigt at folde forældrerettighedsbegrebet ud og vise, hvilke interesser forældrerettigheder skal beskytte. 
Forældrerettigheder udgør en speciel klasse af rettigheder. Normalt giver rettigheder rettighedsholderen frihed til at bestemme i sager, der vedrører hende selv. Forældrerettigheder, derimod, giver ret til at bestemme over andre individer, nemlig ens børn. Forældre er heller ikke de eneste aktører med interesse i børns uddannelse. I Danmark er der fx undervisningspligt, og forældre kan heller ikke bestemme indholdet af undervisningen. Forældrerettigheder er således begrænset: Staten kan ikke fuldstændig tilsidesætte forældres interesser, men forældre har på den anden side heller ikke fuldstændig råderet over deres børns uddannelse. Det rejser spørgsmålet om, hvor meget forældre kan bestemme på vegne af deres børn. Hvad er omfanget af forældrerettigheder? Jeg skal forsøge at vise, at forældre har ret til at vægte deres egne børns interesser højere end andre børns, selvom det øger uligheden i samfundet, men at det ikke nødvendigvis inkluderer en ret til at vælge skole.

At sige, at forældre har en rettighed til at vælge, hvilken skole deres barn skal gå på, er ensbetydende med at sige, at de har en interesse i deres børns uddannelse, som er tilstrækkelig tungtvejende til at pålægge andre en pligt til at beskytte og fremme denne interesse. De to filosoffer, Harry Brighouse og Adam Swift (2006, 2009), har udviklet en attraktiv teori om forældrerettigheder, som de begrunder i, hvad de kalder „family values“, eller i værdien af familien som institution. Teorien er kompleks, så jeg kan ikke diskutere alle dens komponenter her. Brighouse og Swift tager udgangspunkt i familiens betydning for forældrenes og børnenes velfærd:

„....it is widely accepted that all people need to participate in family life as children in order to become fully flourishing adults: they need secure attachments to particular adults who will give them the kind of loving attention necessary for them to become capable of loving themselves and others. That claim is important and true. Yet we also endorse the controversial view that for many adults having a parental relationship with a child makes a distinctive and important contribution to their flourishing. For us, this fact plays a role in justifying the institution of the family (Brighouse and Swift 2009, 53)“.

Familien som institution realiserer nogle værdier, som er vigtige både for forældrenes og børnenes velfærd. Brighouse og Swift opremser fire såkaldte „relationship goods“, hvoraf de tre første knytter an til børnenes interesser og det sidste til forældrenes. For det første er det kærlige bånd, børnene har til forældrene essentielt for deres følelsesmæssige udvikling. For det andet er det vig- tigt for børnenes velfærd at have tilknytning til fortiden, som den bliver formidlet gennem familien. For det tredje nyder børnene godt af den sikkerhed, som kommer af, at nogle har en speciel pligt til at tage sig af dem. Endelig er det gensidige og intime kærlighedsforhold, forældre har til deres børn, en vigtigt komponent i forældrenes velfærd (Brighouse and Swift, 2009). Brighouse og Swift påstår ikke, at voksne skal være forældre for at få et godt liv, men forældreskab er en vigtig og distinkt kilde til velværd. Hvad mere er, den værdi, der ligger i forældreskabet, kan ikke realiseres $\mathrm{i}$ andre forhold $-\mathrm{i}$ den forstand realiserer familien nogle distinkte og essentielle interesser både for børnene og forældrene.

Forældrerettigheder, eller familien som institution, er således retfærdiggjorte, fordi de beskytter goder, som kun kan realiseres i en familie. Forældrerettigheder sikrer et frirum, hvor forældre kan vægte deres egne og deres børns interesser højere end andres interesser, også selvom det fører til mere ulighed i uddannelsesmuligheder. Spørgsmålet er imidlertid, hvor stort dette frirum bør være. Det er klart, at eftersom forældrerettigheder er begrundet $\mathrm{i}$ værdien af forholdet mellem forældre og barn, skal forældre have frihed til at indgå i de aktiviteter, som er konstituerende for det forhold. At læse godnathistorier for sit barn er et paradigmeeksempel på en aktivitet, som er konstituerende for et intimt forhold til sit barn. Ligeledes bør forældre have frihed til at dele deres interesser med deres børn, fx ved at melde dem ind i en bestemt sportsklub eller en anden slags forening, herunder religiøse foreninger. Som Brighouse og Swift skriver:
„Without substantial opportunity to share himself intimately with his child, in ways that reflect his own judgments about what is valuable, the parent is deprived of the ability to forge and maintain an intimate relationship, and the child is deprived of that relationship (...) Imagine that parents are barred from engaging in theses or relevantly similar activities, or, less drastically, that they are made very difficult; the opportunities for realizing the familial relationship goods that justify the family would be severely limited (Brighouse and Swift 2009, 57)“.

At læse godnathistorie for ens barn og indgå i andre aktiviteter, som er konstituerende for en intim forældre-barn relation, har vi en moralsk ret til, også selv om disse aktiviteter leder til større ulighed. Lighed er en vigtig værdi, men den vejer ikke tungere end den værdi, der ligger i at have et intimt forhold sine børn.

Deroverfor står alle de aktiviteter, som ikke på lignende vis er essentielle for realiseringen af de familiære 
relationsværdier. Som Brighouse og Swift nævner, kan forældres ret til at vælge en elitær privatskole ikke begrundes ud fra de familiære relationsværdier $(2009,58)$. Man kan sagtens opretholde et intimt forhold til at sine børn, selvom man ikke har frihed til at vælge en privatskole. Det afgørende spørgsmål er, om forældrerettigheder, således forstået, kan begrunde det frie skolevalg. Umiddelbart er svaret nej. At have frihed til at vælge en skole $i$ et andet skoledistrikt, end det man tilhører, er ikke en nødvendig forudsætning for at kunne realisere de familiære relationsværdier. Forældre kan opretholde et intimt forhold til deres børn og nyde de goder, som følger af forældreskabet, selvom de ikke har mulighed for at vælge en anden skole end den lokale skole. Derfor kan det frie skolevalg ikke begrundes med henvisning til, at forældre har en moralsk ret til at vælge skole for deres barn. De interesser, forældre har i at kunne vælge skole, er ikke tungtvejende nok til at begrunde en rettighed til frit skolevalg, og de er derfor heller ikke tungtvejende nok til at opveje de uligheder i uddannelsesmuligheder, som kan følge af det frie skolevalg.

Det kan indvendes mod Brighouse og Swift, at visse former for skolevalg er konstituerende for at have et intimt forhold til sine børn. Religiøse forældre kan fx have en stærk interesse $\mathrm{i}$ at sende deres barn $\mathrm{i}$ en religiøs skole, som meget vel kan være begrundet $i$ et ønske om og et behov for at kunne opretholde et intimt forhold til deres børn. ${ }^{13}$ Jeg er enig $i$, at det at kunne dele sine religiøse interesser med sine børn kan være konstituerende for et intimt forhold mellem barn og forældre. Det er imidlertid tvivlsomt, om det kan begrunde en ret til at vælge religiøse skoler. At sende sit barn til en religiøs fri- eller privatskole er ikke den eneste måde, forældre kan dele deres værdier med deres børn på. Forældre kan dele deres religiøse interesser med deres børn i en lang række andre sammenhænge, fx privat eller i religiøse foreninger (Swift 2003: 70).

\section{Aarhus- og Københavnermodellen}

Den foregående diskussion kan give det indtryk, at jeg er imod skolevalg som sådan. Det er imidlertid ikke rigtigt. Jeg har argumenteret for, at retten til frit skolevalg ikke begrundes i forældrerettigheder. Det betyder imidlertid ikke, at vi skal opgive det frie skolevalg, eftersom der kan være alternative måder at imødegå de negative effekter på end at forbyde det frie skolevalg. I forhold til privatskoler kunne man fx pålægge dem strengere krav om at optage eller ligefrem reservere pladser til resursesvage elever. Man vil dermed sikre en mere hensigtsmæssig elevsammensætning og samtidig bibeholde de gode ting, som privatskoler også bidrager med, som fx større pædagogisk diversitet. Endvidere kan det heller ikke udelukkes, at alternativerne til det frie skolevalg vil føre til endnu mere ulighed og/eller segregation. Alt hvad jeg indtil videre har vist er, at der ikke er en principiel grund, begrundet $\mathrm{i}$ forældrerettigheder, til at have et frit skolevalg.

Som nævnt kan der være andre måder at imødegå de negative konsekvenser af det frie skolevalg på. København og Aarhus Kommune, som oplever det største fravalg af den lokale folkeskole, har iværksat forskellige politiske tiltag med det formål at sikre en bedre spredning af tosprogede elever. Den såkaldte Københavnermodel for integration forsøger at afstedkomme dette dels ved at tilbyde udvalgte tosprogede elever pladser på skoler med få tosprogede elever; dels ved at gøre skoler med mange tosprogede elever mere attraktive for etnisk danske elever. ${ }^{14}$ Københavnermodellen bygger på frivillighed og tiltagene retter sig både mod etnisk danske forældre og indvandrerforældre. Overordnet set har københavnermodellen ført til en bedre spredning af tosprogede elever, om end noget tyder på, at det er lettere at flytte tosprogede elever til en skole med få tosprogede end at bibeholde etsprogede elever på skoler med mange tosprogede elever (Københavns Kommune 2008). På trods af det, er det langtfra lykkedes at undgå ,ghettoskoler“. Der er stadig skoler (fx Klostervængets skole på Østerbro) med en andel af elever med anden etnisk baggrund på $86 \%$ og hvor $82 \%$ af forældrene er på overførelsesindkomster. Københavnermodellen kan ses som et forsøg på at fremme det kommunitaristiske ideal uden at give køb på det frie skolevalg. Selvom politikerne ikke fremhæver lighedsidealet, er der næppe tvivl om, at det ligger i baggrunden, eftersom der er en stærk sammenhæng mellem forældrenes etniske baggrund og deres socioøkonomiske position. Etnisk blandede skoler vil derfor alt andet lige også fremme uddannelseslighed.

I Aarhus er man gået mere radikalt til værks og ophævet det frie skolevalg for visse grupper. Kommunen sprogtester alle tosprogede børn, og sender børn med de dårligste sprogkundskaber til skoler med færre tosprogede elever. Kommunen sørger for bustransport til den nye skole. Der er uenighed om, hvorvidt modellen har været en succes. En evaluering foretaget af Konsulenthuset Brøndum og Fliess viser dog, at $77 \%$ af de tvangsflyttede børn har opnået en markant forbedring i deres sprogkundskaber fra børnehaveklassen til 3. klasse (Brøndum og Fliess 2010). Aarhus-modellen kan begrundes både ud fra lighedsidealet og det kommunitaristiske ideal. Givet kammeratskabseffekten, vil det fremme uddannelseslighed at sende resursesvage elever til skoler med flere resursestærke elever. Samtidig vil det også skabe flere etnisk blandede skolemiljøer i overensstemmelse med det kommunitaristiske ideal. 
Der er imidlertid aspekter ved Aarhus-modellen, som er moralsk problematiske. For det første kan Aarhus-modellen beskyldes for forskelsbehandling. Som ordningen er nu, er det kun tosprogede elever, som bliver sprogtestet. Dermed er det kun indvandrerforældre, som risikerer at miste deres ret til frit skolevalg. Dertil kommer, at selvom der er en markant sammenhæng mellem tosprogethed og manglende danskkundskaber, kan det ikke udelukkes, at nogle etnisk danske elever også ville kunne have gavn af at blive flyttet til en skole med flere resursestærke elever. Aarhus-modellens ensidige fokusering på tosprogede elever illustrerer, hvad der sker, når man, som det er tilfældet i det nuværende politiske klima, ensidigt fokuserer på sammenhængen mellem etnicitet og manglende skolekundskaber. Hvis målet derimod er at fremme lighedsidealet og socioøkonomisk integration, er der ingen grund til at begrænse tvangsflytning til tosprogede børn med manglende danskkundskaber. Det er selvfølgelig et kontroversielt forslag, og det er tvivlsomt, om de lighedsmæssige fordele ved at indføre et sådant forslag vil opveje ulemperne, men det er værd at overveje, om der skal gøres en mere aktiv indsats for at skabe socioøkonomisk blandede klasser for dermed at fremme uddannelseslighed.

Et andet problematisk aspekt ved Aarhus-modellen er, at det udelukkende er de resursesvage elever, der bliver bedt om at skifte skole. Man kunne opnå samme effekt ved at flytte resursestærke elever til skoler med mange resursesvage elever. En mulig begrundelse for at tvangsflytte de svage elever er, at eftersom det er de svage elever, der har et problem, er det også dem, der skal flytte. Det er imidlertid ikke et holdbart argument. Lighedsidealet bygger netop på den antagelse, at vi ikke er ansvarlige for, hvilket socialt miljø, vi er født ind i. Det gælder ligeså vel de resursestærke som de resursesvage elever. Det er derfor heller ikke klart, hvorfor det er de resursesvage, der alene skal bære de omkostninger, der er forbundet med at flytte til en anden skole.

\section{Afsluttende bemærkninger}

Som sagt har jeg ikke argumenteret for en afskaffelse af det frie skolevalg eller et forbud mod privatskoler. Jeg har derimod forsøgt at vise, at man som forældre ikke har en moralsk ret til skolevalg, og at idealet om uddannelseslighed er et krævende ideal. På nuværende tidspunkt er der heller ikke politisk opbakning til en afskaffelse af det frie skolevalg. Det kan heller ikke udelukkes, at en ordning, som $\mathrm{fx}_{\mathrm{x}}$ Københavnermodellen, på længere sigt kan vise sig at være løsningen på de uligheder, som frit skolevalg leder til. Det er komplicerede empiriske spørgsmål, som det er svært at sige noget præcist om. Men givet at forældre ikke har en moralsk ret til frit skolevalg, kan der argumenteres for at tage mere radikale løsninger i brug, for at modvirke de negative fordelingsmæssige konsekvenser af frit skolevalg.

\section{Noter}

1 En anden vigtig lovændring i forhold til tidligere er, at skoleledere ikke længere kan afvise elever af pædagogiske grunde, men udelukkende med henvisning til kapacitetsbegrænsninger på den pågældende skole.

2 I Danmark giver staten et beløb, som svarer til $75 \%$ af den normale udgift, som folkeskolen har pr. elev

3 Bemærk, at Rambøll-rapporten udelukkende ser på effekterne af lovændringen.

4 Se fx Rawls' (1999) diskussion (\$12).

5 Problemet er her, at nogle børn har så alvorlige kognitive handikaps, at det er umuligt at stille dem lige så godt som andre, medmindre vi er villige til at handikappe de raske børn. Den såkaldte „levelling down objection“ er vigtig. En måde at imødegå den på er ved at sige, at samfundet kun bør udligne uligheder, der skyldes sociale forhold, men ikke uligheder, der kan spores tilbage til naturlige (genetiske) omstændigheder. Det er kontroversielt, hvorvidt der er en normativ signifikant distinktion mellem sociale og naturlige uligheder, men jeg skal ikke diskutere det yderligere her, dels fordi målet ikke er at give et fuldstændigt forsvar for lighed som ideal, dels fordi den form for ulighed, som det frie skolevalg kan tænkes at generere, er social betinget.

6 Olsen (2009) er en af de førende danske fortalere for enhedsskolen.

7 Højst sandsynligt vil der være en vis grad af sammenfald mellem de to former for segregation, især hvis vil taler om 1. og 2. generationsindvandrer, men det ser jeg bort fra her.

8 Der kan være flere grunde til at det forholder sig sådan, men to vigtige er, at forældre med længerevarende uddannelse ofte er i bedre stand til at hjælpe deres børn med lektier, og at forældrenes uddannelsesniveau ligeledes har en positiv effekt på børnenes ambitioner og arbejdsmoral.

9 Jeg siger alt andet lige, fordi hvis der blot er tale om at skabe separate klasser for de mindste årgange, fx 1.-3. klasse, kan fortalerne for det kommunitaristiske ideal måske acceptere det, fordi det på længere sigt vil lette integrationen for elever med dansk som andet sprog.

10 Shlomi (2011) diskuterer, hvordan egalitarister skal forholde sig til det faktum, at familien er en vigtig årsag til ulighed. Et klassisk værk i den filosofiske litteratur er Fishkin (1983).

11 At sige, at der en grund til at forbyde forældre at læse godnathistorier for deres børn, betyder ikke, at samfundet, alt taget i betragtning, bør gøre det, da der kan være andre grunde, fx forældrerettigheder, som jeg diskuterer i afsnit 3, til at tillade forældre at læse godnathistorier for deres børn. Men selve det, at der er en grund, er kontroversielt. Mange vil umiddelbart mene, at der intet problematisk er ved at en sådan aktivitet.

12 En lignende formulering findes i Artikel 26 i The Human Declaration of Rights

13 Jeg antager selvfølgelig, at religiøse skoler lever op til samfundets krav vedrørende kvaliteten og indholdet af undervisningen.

14 Det er elever, som enten har gået i en børnehave med mange tosprogede elever, eller som ikke har gået i børnehave, men har modtaget sprogstimulering mindst 15 timer om ugen.

\section{Referencer}

Brighouse, H 2000, School Choice and Social Justice, Oxford University Press, Oxford. 
Brighouse, H 2007, 'Educational Justice and Socio-Economic Segregation in Schools', Journal of Philosophy of Education, vol. 41, no 4, pp 575-90.

Brighouse, H og Swift, A 2006, 'Parent's Rights and the Value of the Family', Ethics, vol.117, no. 1, pp. 80-108.

Brighouse, H og Swift, A 2009, 'Legitimate Parental Partiality', Philosophy \& Public Affairs, vol. 37, no. 1, pp. 43-80.

Brøndum og Fliess 2010, 'Evaluering af model for henvisning af skolebegyndere med dansk som an-detsprog', http://www.aarhus.dk/ / media/Dokumenter/MBU/VI/Evaluering-af-modtagerskoler/Baggrundsrapport.ashx

Callan, E 1997, Creating Citizens: Political Education and Liberal Democracy, Oxford University Press, Oxford.

Cevea, 2010a, 'Privatskolerne Danmarkskort - Storbyerne svigter folkeskolen', http://www.cevea.dk/wp-content/uploads/270610NOTATPrivatskolernes-Danmarkskort---Storbyerne-svigter-folkeskolen1. pdf

Cevea, 2010b, 'De private enklaveskoler svigter det sociale ansvar', http://www.cevea.dk/notat-de-private-enklaveskoler-svigter-detsociale-ansvar/
Cevea, 2010c, 'Fællesskabet betaler for privatskolernes succes', http:// www.cevea.dk/wp-content/uploads/270610NOTAT-Fællesskabetbetaler-for-privatskolernes-succes.pdf

Fishkin, J 1983, Justice, Equality of Opportunity and the Family, Yale University Press, New Haven.

Københavns Kommune 2008, 'Københavnermodellen for Integration - tiltag som virker!', statusnotat.

Olsen, L 2009, Den sociale smeltedigel, Forlaget Sohn, Rødovre.

Rambøll Management 2007, 'Evaluering af mere frit skolevalg', http:// www.uvm.dk/ /media/Files/Udd/Folke/PDF08/E/070401_eva_ frit_skolevalg.ashx

Rangvid, BS 2006, 'Living and Learning Separately? Ethnic Segregation of School Children in Copenhagen', arbejdspapir, AKF.

Rangvid, BS, 2008, 'Skolegennemsnit af karakterer ved folkeskolens afgangsprøver. Korrektion for social baggrund, arbejdspapir, AKF.

Rangvid, BS 2010, 'School Choice, universal vouchers and native flight out of local public schools', European Sociological Review, vol. 6, no. 3, pp. 319-35.

Rawls, J 1999 [1971], A Theory of Justice, revised edn., Harvard University Press, Cambridge.

Shlomi, S 2011, 'If you are a luck egalitarian, how come you read bedtime stories to your children?', Critical Review of International Social and Political Philosophy, vol. 14, no. 1, pp.23-40.

Swift, A 2003, How not to be a hypocrite: school choice for the perplexed parent, Routledge, London. 